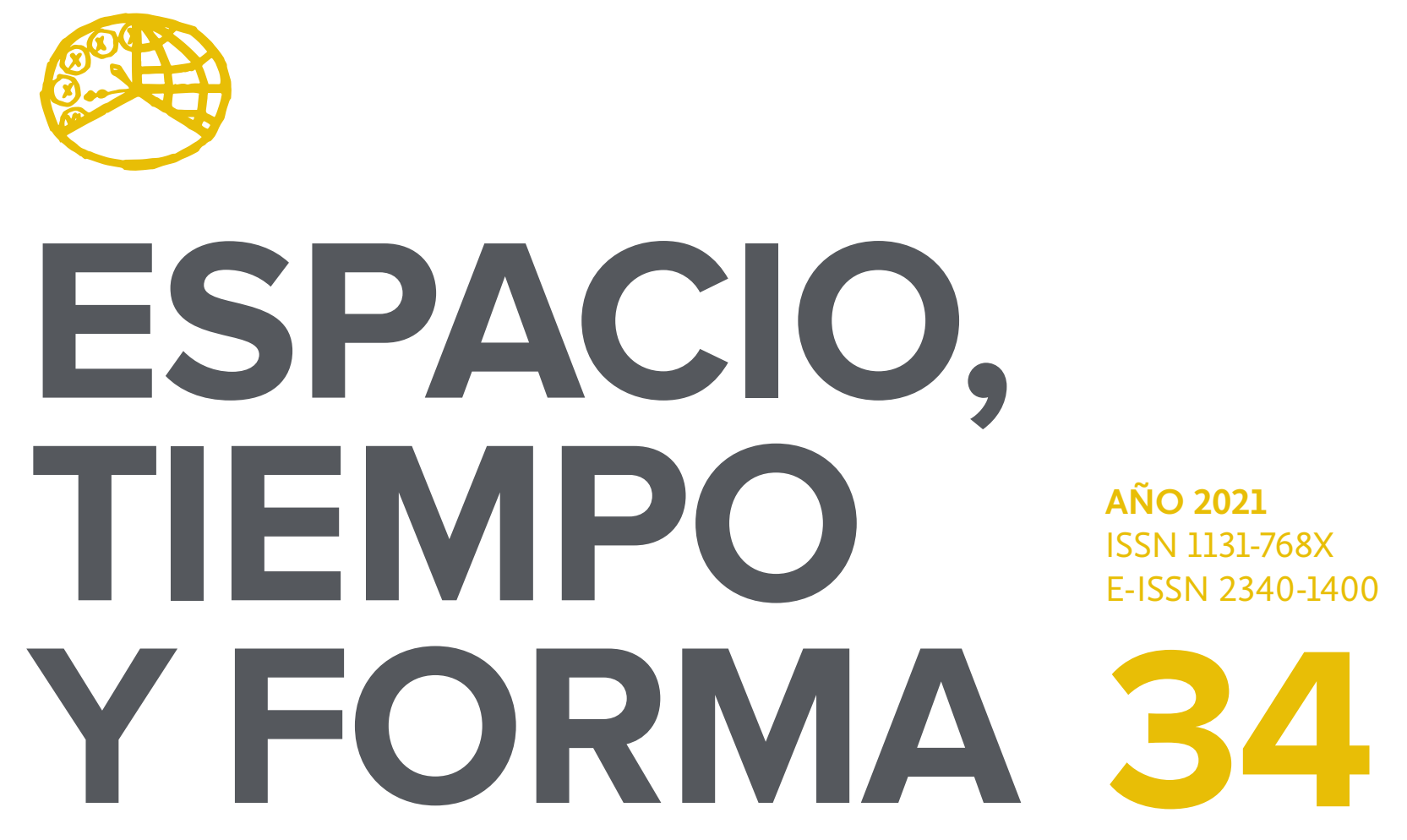

SERIE IV HISTORIA MODERNA

REVISTA DE LA FACULTAD DE GEOGRAFÍA E HISTORIA

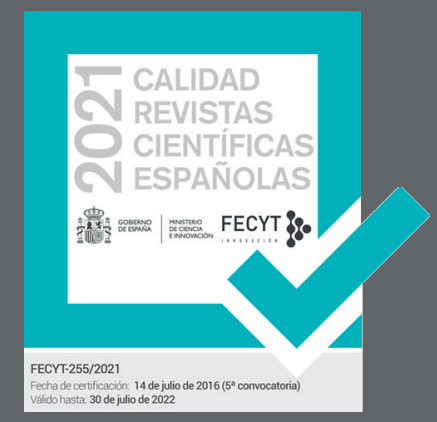




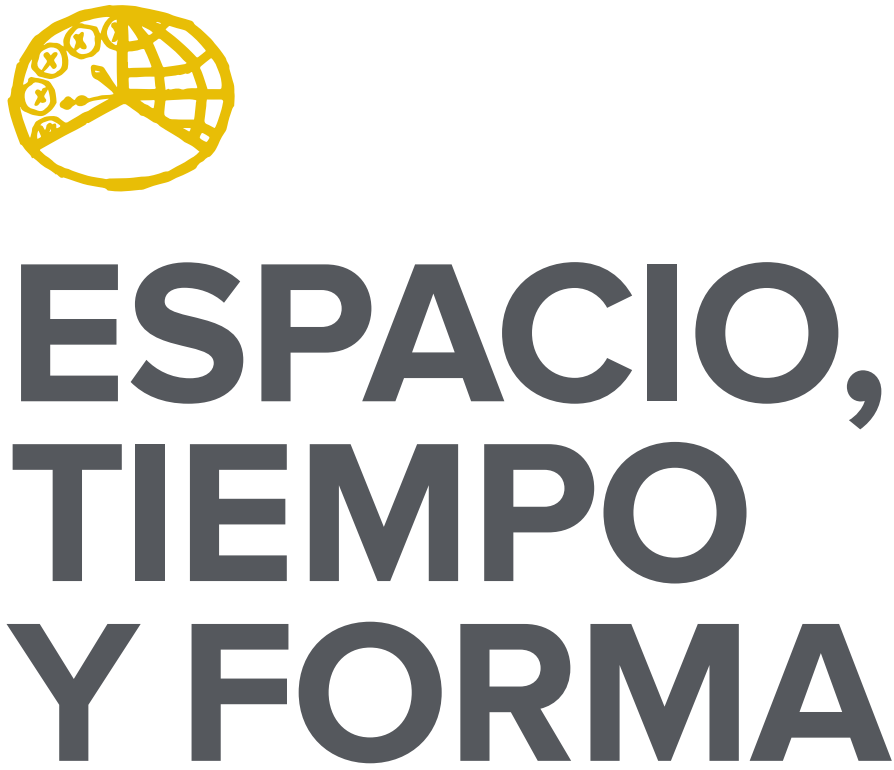

AÑO 2021

ISSN 1131-768X

E-ISSN 2340-1400

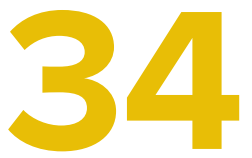

SERIE IV HISTORIA MODERNA

REVISTA DE LA FACULTAD DE GEOGRAFÍA E HISTORIA

DOI: https://doi.org/10.5944/etfiv.34.2021

\section{UกED}

UNIVERSIDAD NACIONAL DE EDUCACIÓN A DISTANCIA 
La revista Espacio, Tiempo y Forma (siglas recomendadas: ETF), de la Facultad de Geografía e Historia de la UNED, que inició su publicación el año 1988, está organizada de la siguiente forma:

$$
\begin{aligned}
& \text { SERIE I - Prehistoria y Arqueología } \\
& \text { SERIE II - Historia Antigua } \\
& \text { SERIE III - Historia Medieval } \\
& \text { SERIE IV - Historia Moderna } \\
& \text { SERIE V - Historia Contemporánea } \\
& \text { SERIE VI - Geografía } \\
& \text { SERIE VII - Historia del Arte }
\end{aligned}
$$

Excepcionalmente, algunos volúmenes del año 1988 atienden a la siguiente numeración:

$$
\begin{aligned}
& \mathrm{N} .^{\circ} 1 \text { - Historia Contemporánea } \\
& \mathrm{N}^{\circ} 2 \text { - Historia del Arte } \\
& \mathrm{N} .^{\circ} 3 \text { - Geografía } \\
& \mathrm{N} .^{\circ} 4 \text { - Historia Moderna }
\end{aligned}
$$

ETF no se solidariza necesariamente con las opiniones expresadas por los autores.

\author{
UNIVERSIDAD NACIONAL DE EDUCACIÓN A DISTANCIA \\ Madrid, 2021 \\ SERIE IV · HISTORIA MODERNA N. ${ }^{\circ} 34,2021$ \\ ISSN $1131-768 X \cdot$ E-ISSN 2340-1400 \\ DEPÓSITO LEGAL \\ M-21.037-1988 \\ URL \\ ETF IV · HISTORIA MODERNA · http://revistas.uned.es/index.php/ETFIV \\ DISEÑO Y COMPOSICIÓN \\ Carmen Chincoa Gallardo · http://www.laurisilva.net/cch \\ Impreso en España · Printed in Spain
}

(c) (7) (8) Esta obra está bajo una licencia Creative Commons Reconocimiento-NoComercial 4.0 Internacional. 


\section{MONOGRÁFICO · SPECIAL ISSUE}

LA POLÍTICA ULTRAMARINA DE LAS MONARQUÍAS

IBÉRICAS (CIRCA 1700-1750): UNA HISTORIA

DE FRACASOS Y ÉXITOS RELATIVOS

THE OVERSEAS POLICY OF THE IBERIAN MONARCHIES (CIRCA 1700-1750): A HISTORY OF FAILURES AND RELATIVE SUCCESSES 



\title{
SOBRE ESTE MODO DE RESOLVER \\ E DESPACHAR OS NEGÓCIOS. EL DECLIVE DEL CONSELHO ULTRAMARINO \\ Y EL AUGE DE LOS SECRETARIOS DE ESTADO EN PORTUGAL DURANTE LA PRIMERA MITAD DEL SIGLO XVIII
}

\author{
SOBRE ESTE MODO DE RESOLVER E DESPACHAR \\ OS NEGÓCIOS. THE DECLINE OF THE \\ OVERSEAS COUNCIL AND THE RISE OF THE \\ SECRETARIES OF STATE IN PORTUGAL DURING \\ THE FIRST HALF OF THE 18TH CENTURY
}

Maria Fernanda Bicalho'

Recibido: 15/12/2020 - Aceptado: 22/04/2021

DOI: https://doi.org/10.5944/etfiv.34.2021.29356

\section{Resumen ${ }^{2}$}

Uno de los aspectos que llama la atención a quienes estudian los imperios ultramarinos de la Edad Moderna es la producción de un «océano de papeles». La Corona portuguesa construyó una red de comunicación y circulación de informaciones y saberes relativamente sofisticada con el objetivo de establecer formas de gobierno y de explotación económica sobre territorios alejados entre síy con poblaciones diferenciadas. La propuesta de este artículo será un análisis de las dos institucionales principales -el Conselho Ultramarino y la secretaría de Estadoresponsables de la elaboración de las políticas dirigidas al gobierno de las conquistas, así como para la producción de conocimiento y circulación de informes entre el reino y el Ultramar. El objetivo específico será el análisis de la interlocución entre las diferentes instituciones y agentes de Brasil -ministros reales y elites coloniales-, el Conselho Ultramarino, las secretarías de Estado y, en última instancia, el monarca.

1. Universidade Federal Fluminense; mfbicalho@uol.com.br

2. Traducción realizada por Roberto Quirós Rosado (Universidad Autónoma de Madrid). Este estudio forma parte del proyecto «FAILURE: Reversing the Genealogies of Unsuccess, 16th-19th Centuries» (H2020-MSCA-RISE, Grant agreement: 823998), dentro de las líneas de trabajo establecidas en el WP4 «Unsuccessful polities, from empire to nations, and international relationships», y se ha desarrollado en el marco del proyecto Reloj de Indias: la proyección europea en el Atlántico, 1665 -1700 (SI1/PJI/2019-00270), concedido por la Comunidad de Madrid y la Universidad Autónoma de Madrid. 
Palabras clave

Conselho Ultramarin; secretarías de Estado; Portugal; Brasil; siglo XVIII

\begin{abstract}
One of the aspects that draws the attention of those who study the overseas Empires of the Early Modern Age is the production of an «ocean of papers». The Portuguese Crown built a relatively sophisticated network of communication and circulation of information and with the aim of establishing forms of government and economic exploitation on territories that were far from each other and had differentiated populations. The proposal of this article will be an analysis of the two main institutions -the Conselho Ultramarino and the Secretaria de Estadoresponsible for the elaboration of policies aimed at the government of conquests, as well as for the production of knowledge and circulation of reports between the kingdom and the overseas colonies. The specific objective will be the analysis of the interlocution between the different agents of Brazil -royal ministers and colonial elites-, the Conselho Ultramarino, the Secretaria de Estado and the monarch.
\end{abstract}

\title{
Keywords
}

Conselho Ultramarino; secretariats of State; Portugal; Brazil; I $8^{\text {th }}$ Century 
El primer intento de creación de un órgano especializado en los asuntos ultramarinos portugueses tuvo lugar en el periodo de la anexión de Portugal a la Monarquía de España. El regimiento del Conselho da Índia, de 25 de julio de I604, le hacía gestionar los negocios relativos a los dominios extraeuropeos de la Corona, excepto las islas Azores y Madeira y los presidios del norte de África. De acuerdo con una consulta del Consejo de Portugal madrileño, de i608, que indicaba nombres para su presidencia, recaerían en el primero «as mais substanciais matérias da Índia, e dos mais Estados ultramarinos se tratam» .

Esta institución tiene escasas evidencias documentales, o estudios profundos, sobre los motivos que llevaron a los Austrias a su creación, y mucho menos sobre su extinción diez años después, en I6I4. Existen, sin embargo, algunos trabajos dedicados al mismo y a sus dinámicas, sobre todo en relación al Estado da Índia ${ }^{4}$. Lo que tal vez pueda dilucidar las razones que llevaron a Felipe III (II de Portugal) a determinar su formación sería tener en cuenta una coyuntura muy específica para los dominios lusos en tierras índicas a comienzos del Seiscientos, ante la amenaza neerlandesa e inglesa que desafiaba el dominio de Portugal en las costas asiáticas. Pese a que dicha situación se mantendría en el tiempo, que sería incluso imposible de soslayar, el Conselho da Índia fue extinto por carta real de 2I de mayo de I6I4. A partir de entonces, el expediente de las cuestiones ultramarinas retornaría a los demás tribunales lisboetas, como el Desembargo do Paço, el Conselho da Fazenda e, incluso, la Mesa da Consciência e Ordens.

\section{LA INDEPENDENCIA DE PORTUGAL Y LA GUERRA DE RESTAURAÇÃO. LA SEGUNDA MITAD DEL SEISCIENTOS}

En el periodo inmediatamente posterior a la Restauración portuguesa (I640), en medio de las guerras en Europa contra Felipe IV y contra los holandeses en Pernambuco y Angola, Juan IV no podía consolidar las condiciones necesarias -tanto en la guerra y diplomacia exterior, como en los asuntos internos de Portugal- que le garantizasen un sólido y duradero dominio. Dada la relativa fragilidad de la persona regia, la afirmación de autonomía y la capacidad de gobierno del reino y del mantenimiento de las conquistas ultramarinas eran bastante inciertas ${ }^{5}$. Fue en esta coyuntura de incertidumbres cuando el nuevo monarca creó, el I4 de julio de I642, el Conselho Ultramarino, justificando su institución de la siguiente manera:

«Pelo estado em que se acham as cousas da Índia, Brasil, Angola e mais conquistas do reino, e pelo muito que importa conservar e dilatar o que nelas possuo e recuperar o que se perdeu nos tempos passados, e ser precisamente necessário, antes que os danos que ali tem padecido esta Coroa passem adiante, prover de remédio com toda aplicação e por todos os meios justos e possíveis: resolvi nomear Tribunal separado em que particularmente

3. AGS, Secretarías Provinciales, libro 1479, f. 152 r.

4. LUZ, 1952; BORGES, 2014.

5. Costa y Cunha, 2006; LOUReiro, 2014. 
tratem os negócios daquelas partes, que até agora corriam por ministros obrigados a outras ocupações, sendo as das conquistas tantas e da qualidade que se deixa entender, e que este Tribunal tenha no Paço, a casa que se Ihe assinará e se chame Conselho Ultramarino» ${ }^{6}$.

Aunque el regimiento del Conselho Ultramarino, ampliamente basado en el precedente Conselho da Índia, databa de I642, su primera reunión tendría lugar en diciembre del año siguiente. En ella, los consejeros se dedicaron a discutir y evaluar sus disposiciones reguladoras y defender ante el rey las modificaciones que, a su parecer, minimizaban su preeminencia frente a otros tribunales del reino. De acuerdo con Edval de Souza Barros,

«Cuidava-se de zelar pelas jurisdições ainda compartilhadas com os outros tribunais, e as razões adiantadas tanto procuravam garantir um controle mais estreito sobre os cargos que ficaram de fora de sua alçada, quanto prevenir a intromissão de outras instâncias nos trâmites burocráticos que se entendiam exclusivos. Apresentavam-se, assim, três pontos principais, evitando-se questionar frontalmente a decisão real, fosse por meio do recurso ao precedente, da busca da isonomia de prerrogativas entre tribunais, do melhor serviço régio ou da interpretação própria franqueada pela letra do regimento»’.

El primer punto se refería a su exclusión de la consulta para el nombramiento de los obispados y demás negocios eclesiásticos de Ultramar. El segundo trataría de la interferencia y la centralidad del secretario das Mercês en el trámite de los pareceres de partes sobre las peticiones de retribución de servicios prestados. En el decimosegundo punto del regimiento del Conselho Ultramarino se estipulaba que después de despachadas por el monarca, las consultas serían enviadas a dicho plumista, a fin de ser encaminadas a sus beneficiarios por este sujeto. En el entender de los consejeros, este trámite llenaría de descrédito a su tribunal, dado que en los demás era usual que sus propios presidentes u otros oficiales en su lugar pasaran las portarias y órdenes resultantes de las decisiones reales ${ }^{8}$. Tal novedad no aparecía en el regimento del Conselho da Índia, lo que redundaba en la pérdida de autoridad y calidad del Ultramarino. El tercer punto aludiría a la emulación con el Conselho da Fazenda, procurando limitar la intromisión de éste en los asuntos extraeuropeos. Según Edval Barros, «os atritos com o Conselho da Fazenda, manifestos desde o primeiro dia da existência do Conselho Ultramarino, foram recorrentes durante o periodo de 'guerra encoberta' com os neerlandeses no Atlântico e no Índico»9.

\footnotetext{
6. Caetano, 1967.

7. BARROS, 2008: 107

8. En el inicio del reinado de Juan IV sólo colaboraban con el monarca un único secretario de Estado. El alvará de 29 de noviembre de 1643 dividiría el despacho por dos oficinas: la de Estado y la de Mercës e Expediente. Marcello Caetano alude a una carta regia previa, de 11 de enero de 1616, que explicitaba «o modo por que se devem fazer as respostas dos negócios da Índia e conquistas ultramarinas que se consultarem nos Tribunais». La decisión bragancista era que se procediese en la misma forma que «se usava antes da criação do Conselho da Índia»: las resoluciones del soberano basadas en las consultas de los consejos pasarían por la secretaría de Estado, que a su vez notificaría a los respectivos tribunales para que gestionasen los negocios despachados por ellos, y no por la secretaría. CAETANO, 1967: 34.

9. BARROS, 2008: 108 .
} 
Los conflictos de jurisdicción entre el Conselho Ultramarino y los demás tribunales regnícolas no finalizarían en sus primeros meses de vida, ni siquiera en los primeros años de funcionamiento. Pervivirían durante toda la mitad del siglo XVII, incluso sobrevivieron en el Setecientos. Para comprenderlos mejor es preciso conocer, al menos, la relevancia de tres capítulos de su regimiento, que a la sazón serían los más utilizados en las consultas en que el Conselho defendía sus prerrogativas frente a la intromisión de los demás. Así, en el capítulo sexto, datado el I4 de julio de I642, Juan IV afirmaba tener a bien que a dicho tribunal

«pertençam todas as matérias e negócios de qualquer qualidade que forem, tocantes aos ditos Estados da Índia, Brasil e Guiné, Ilhas de São Tomé e Cabo Verde e de todas as mais partes ultramarinas, tirando as ilhas dos Açores e da Madeira e lugares da África, e por ele há de correr a administração da fazenda dos ditos Estados; e a que deles vier ao Reino se administrará pelo Conselho da Fazenda, que correrá também com os empregos e retornos das carregações».

De acuerdo con el capítulo noveno,

«E por este mesmo Conselho Ultramarino se me consultará o provimento de todos os ofícios de justiça, guerra e fazenda, e por ele passarão as cartas e provisões que deles se houverem de fazer, e as patentes e despachos que houverem de levar os vice-reis, governadores e capitães que para as ditas partes forem providos, tirando a provisão dos bispados e mais lugares e negócios eclesiásticos, porque esses hei por bem se façam pelo modo e forma que até agora se faziam [por la Mesa da Consciência e Ordens]».

De la misma forma, el decimocuarto capítulo disponía que

«E para que o dito Conselho me possa melhor servir e não haja encontros entre ele e os mais Conselhos e Tribunais sobre os negócios que a cada um tocarem, hei por bem e declaro que de todas as coisas declaradas neste Regimento conheça o dito Conselho pela maneira nele declarada sem que outro algum Conselho ou Tribunal se possa intrometer nelas ainda que até agora costumassem convir nele e lhe pertençam por seus regimentos e provisões porque no que forem contra o conteúdo neste meu regimento as hei por derrogadas e de nenhuma força e vigor» ${ }^{10}$.

Sobre el reparto de atribuciones y competencias con el Conselho da Fazenda, en su primera reunión los consejeros ultramarinos advertían al monarca de sus inconvenientes:

«Porquanto de ordinário sucede diferirem os Conselhos no parecer, seguindo-se daqui frieza e dilação, quando em um se executar o que o outro the parece, vindo tudo a resultar em

10. Apud CAETANO, 1967: 120. 
grande dano da república, e desserviço de Vossa Majestade, o que não acontece quando o mesmo Tribunal executa aquilo que aconselha, e que corre por sua conta e reputação» ${ }^{11}$.

Las imprecisiones del regimiento ante las situaciones que se colocaban, por su dinámica, en los negocios tocantes a Ultramar, y sobre la superposición no demasiado diáfana de las atribuciones de los diversos tribunales lisboetas, llevaron a que las instancias de los consejeros ultramarinos que asesorarían al monarca se multiplicaran. Es el caso de la consulta de 20 de octubre de i654 sobre la pertenencia al Conselho Ultramarino, y no al de Fazenda, de la expedición de las licencias a los navíos extranjeros para ir a las conquistas del reino y, a la vez, a los navíos portugueses para llevar a bordo a extranjeros. Dicho parecer partía de un decreto de Juan IV en que solicitaba al presidente del tribunal privativo de Ultramar, conde de Odemira, que le expusiera lo que le tocaba a dicho cuerpo para que se resolviese la querella sin perjudicar la conservación de su derecho o preeminencia. El conde defendía, antes de nada, su propia condición y posición privilegiada como vedor da Fazenda y, a continuación, la del consejo que presidía. Este sujeto, tiempo atrás y como miembro del Conselho da Fazenda, se había posicionado a favor de la jurisdicción de este órgano en el mismo asunto. Atribuía el cambio de su posición a la coyuntura también mudable, no solo por la política exterior y ultramarina de Portugal, sino por la arquitectura de su polisinodia. Afirmaba que

«Se o Conselho da Fazenda deu em algum tempo licenças, foi por ter então incorporado em si o que tocava das conquistas ao Conselho Ultramarino enquanto não o houve, mas hoje que o há não pode deixar de representar a Vossa Majestade que a jurisdição e faculdade

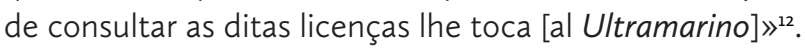

Cabe resaltar que el regimiento del Conselho Ultramarino determinaba que su presidente fuese a la vez vedor da Fazenda da Repartição da Índia y, por tanto, actuase también en el Conselho da Fazenda. Se observa, por tanto, que más allá de la superposición jurisdiccional entre varios tribunales, era recurrente la duplicidad de atribuciones y la pertenencia de un mismo individuo a diversas corporaciones dedicadas al gobierno del reino y a las ligadas a la Casa Real. Ejemplo de ello y de la modificación de los canales por los que se tramitaban los negociados de los consejos y el despacho del monarca es una consulta del Conselho Ultramarino de diciembre de I669, por el que sus miembros solicitaron al príncipe Pedro de Braganza que nombrase un ministro para recibir los requerimientos de las partes, tras ser consultadas por este tribunal, o que las consultas pudiesen ser entregadas a los dos secretarios de Estado y de Mercês, pues de otra forma las resoluciones tomadas podrían ser contrapuestas y se perjudicaría a los solicitantes. La resolución regia consistió en que las consultas serían entregadas al «porteiro da minha câmara, como

11. Apud BARros, 2008: 109.

12. AHU, Conselho Ultramarino, caixa 1, documento 25. 
sempre se fez» ${ }^{13}$. Por un lado, parece que el consejo había logrado del regente que las consultas de mercedes no fuesen despachadas por el secretario -hasta entoncesprivativo. Por el otro, el portero de cámara era un oficial de la Casa Real y no de los órganos de gobierno regnícola, lo que complejizaba las tramas y los canales del expediente administrativo relativo a Ultramar.

Las disputas entre los tribunales lisboetas no incidían en la gestión de los negocios de las conquistas, sino en los mencionados aspectos de preeminencias. En una sociedad profundamente jerarquizada como la del Antiguo Régimen, asegurar la posición de privilegio sería una poderosa marca de distinción entre las personas y los cuerpos que la constituían. Ya en los tiempos del Conselho da Índia, un documento sin firma ni fecha, la Relação sobre a precedência que se deve dar ao Conselho da Índia entre os mais Conselhos e Tribunais deste Reino, defendía la superposición de este tribunal sobre el resto. Aludiría a la separación de las mismas materias en los diferentes consejos lisboetas (Estado, Mesa da Consciëncia e Ordens, Desembargo do Paço, Fazenda): Estado, religión, justicia, guerra y hacienda. Ponderaba ser necesario para el buen gobierno del reino y sus posesiones ultramarinas el orden y la precedencia de los consejos de acuerdo con la calidad de las materias tratadas. Por tanto, el Conselho da Índia, de entre todos los demás, tenía la vocación de ocupar una posición cimera, superior al resto, por tratar al mismo tiempo todos los negociados precedentes en los territorios bajo su jurisdicción ${ }^{\mathrm{I4}}$.

En lo que toca al Conselho Ultramarino, en consulta de 16 de junio de i662, sus miembros se posicionaban en contra de la intromisión del Desembargo do Paço en el arbitraje sobre las dudas de precedencias entre los ministros Luís Mendes de Elvas y Francisco de Miranda Henriques. Este último fue nombrado por Alfonso $\mathrm{VI}$ consejero ultramarino, debiendo tener una posición destacada en las reuniones del tribunal. En paralelo, Mendes de Elvas, por ser el más antiguo, suponía tener derecho a precederlo en las sesiones. Ambos eran letrados. El presidente, conde de Odemira, les comunicó haber ejecutado cuanto el monarca ordenaba con la carta de nominación de Francisco de Miranda, «com o que Luís Mendes se saiu do Conselho dizendo que recorreria a Vossa Majestade». El soberano mandó remitir la petición de Luís Mendes al Desembargo do Paço, para que resolviese la disputa, dando a entender a los miembros del Conselho Ultramarino que «o Desembargo do Paço tem superioridade a este Conselho». Aludiéndose a casos similares sucedidos en otros cuerpos, como la Mesa da Consciência e Ordens, los consejeros afirmaban que, como esta cuestión «toca em preeminência, (...) não é justo que Vossa Majestade a queira tirar a um conselho benemérito em seu serviço, e acrescentá-la a outro, posto que também o seja». ${ }^{15}$

13. AHU, Conselho Ultramarino, caixa 1, documento 56.

14. BA, 51-VI-58, ff. 69r-77v. Relação sobre a precedência que se deve dar ao Conselho da India entre os mais Conselhos e Tribunais deste Reino.

15. AHU, Conselho Ultramarino, caixa 1, documento 41. Sobre los nuevos conflictos surgidos entre el Conselho Ultramarino y el Desembargo do Paço, en particular sobre la jurisdicción de los negocios extraeuropeos, véase la consulta del primero al rey Alfonso VI, en 17 de diciembre de 1664, sobre la intromisión del segundo de ellos, que se juzgaba total salvo en el nombramiento de los letrados para Ultramar, a la par que se solicitaba que todos los papeles 
Complejizando la dinámica de cuerpos, agentes y circuitos de comunicación y de decisión de la monarquía portuguesa, junto a los consejos operaban juntas y secretarías con sus respectivos titulares. En relación a las juntas, su creación provenía de la necesidad de agilizar la resolución de problemas que afectaban cotidianamente al gobierno del reino y sus dominios ultramarinos. De acuerdo con Pedro Cardim,

«para além de desfrutarem de uma jurisdição bastante vasta, as juntas operavam com uma certa independência dos órgãos pré-existentes, admitindo o ingresso de oficiais de carácter comissarial e sendo cada vez mais encaradas como a melhor forma de agilizar o governo e a administração, sobretudo no domínio fiscal e comercial» ${ }^{16}$.

Al constituirse en nuevos instrumentos de decisión, desestabilizándose los canales tradicionales del ejercicio de la política (como los consejos), las juntas y su modo de resolución administrativa fueron considerados por muchos de sus contemporáneos como indeseadas novedades o ejemplos de la perniciosa influencia de la Monarquía de España: así, «governar à castelhana era uma expressão corrente na segunda metade do século XVII, e designava um modo de governação que era cada vez mais encarado como diferente dos estilos e procedimentos considerados mais tradicionais e específicos de Portugal» ${ }^{17}$.

Si la institución de las juntas se observó en el reino luso como una moda castellana, lo mismo puede decirse de la figura del valido. Los casos más conocidos del valimiento fueron los del duque de Lerma ${ }^{18} \mathrm{y}$ del conde-duque de Olivares ${ }^{19}$. En el Portugal restaurado, las privanzas serían experiencias efímeras, dada la disfunción y el desequilibrio del régimen distributivo y gubernativo de una monarquía corporativa. El ejemplo más célebre sería el del escrivão da Puridade, Luís de Vasconcelos e Sousa, conde de Castelo Melhor, durante el reinado efectivo de Alfonso VI (1656-I668). Amenazado el conde por facciones de la aristocracia y por los titulares de los consejos al reunir en su persona, o bajo su poder, un número extraordinario de puestos, honras y mercedes de la Corona, y por monopolizar una gran parte de los mecanismos de decisión, Castelo Melhor sería el chivo expiatorio de una conspiración y de las presiones nobiliarias que se levantaron contra sí y, en este caso, contra el propio soberano ${ }^{20}$.

Junto a las juntas y los validos, para asistir al rey en la toma de decisiones y en el control de la información existía un secretario que, a partir de la creación del Conselho de Estado, acumularía también las funciones de plumista de dicho tribunal. De acuerdo a su regimiento, publicado en 1569 , las atribuciones del secretario de Estado serían asistir a sus reuniones - pero sin derecho a voto- y anotar a las resoluciones tomadas, aparte de los votos y pareceres do los consejeros. Expuestos

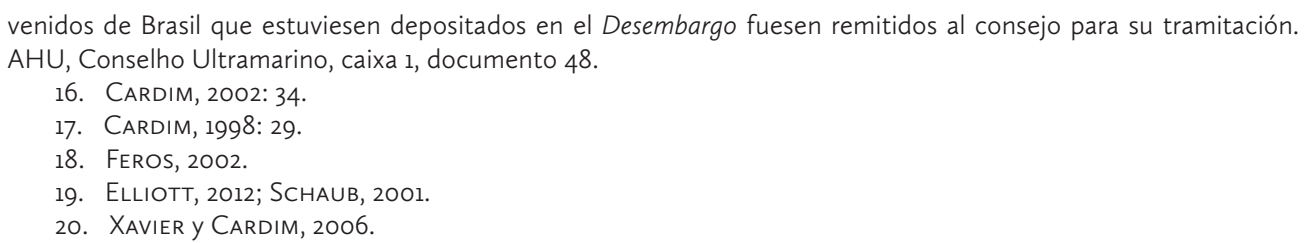


y firmados los asientos, los llevaría personalmente al rey, responsabilizándose en las provisiones tocantes a la decisión regia sobre el negocio en cuestión. Elaborar y circular este tipo de documentación significaba no solo acceder a la forma y los meandros del despacho regio, sino -en algunas coyunturas- tener mayor o menor ingerencia en el proceso de decisiones. Así, serían los secretarios los intermediarios privilegiados en la comunicación de la voluntad real ${ }^{21}$.

Tras la Restauración solo había en Portugal un único secretario de Estado hasta que el 29 de noviembre de I643 dicha oficina fue desdoblada, surgiendo la Seção do Registro Geral das Mercês, también denominada Secretaria das Mercês, que se uniría durante el propio reinado de Juan IV a la Secretaria do Expediente. Según Nuno Monteiro,

«basicamente, à primeira [secretaria de Estado] ficava reservado o despacho das questões de alta política, provimentos de vice-reis, de governadores de províncias, de governadores de armas, de generais da armada, de almirantes e de outros ofícios maiores ligados à guerra, presidência de tribunais e despachos em grandes mercês, ficando para a outra Secretaria [das Mercês e Expediente] as questões menores e as mercês de menos relevância. No entanto, sobre essas matérias da grande política, o Conselho de Estado devia antes ser ouvido» ${ }^{22}$.

La afirmación de los secretarios en la corte dependió, en gran medida, del control sobre el registro y la circulación de papeles y documentos, permitiendo desarrollar capacidades para seleccionar y tratar la información sobre los contenidos de las materias gubernativas, sino también la forma y los mecanismos de búsqueda, tratamiento, archivo y presentación de pareceres y consultas. El hecho de que las secretarías ni siquiera apareciesen en las Ordenações Filipinas solo confirma la distancia entre el reconocimiento formal de un instrumento de poder y su existencia, así como su alcance concreto. Gran parte del poder adquirido por los secretarios provendría de su limitada reglamentación, permitiendo al soberano ir bordeando los procesos de sus tribunales, lo que demuestra su poder político, siempre y cuando no faltase la confianza del monarca, algo que acaecería en determinados momentos traumáticos de la vida cortesana ${ }^{23}$.

Por otro lado, en las coyunturas críticas por los cuales pasó la monarquía portuguesa y sus conquistas durante gran parte del siglo XVII, los consejos de Índia o el Ultramarino fueron activados y ganaron un destacado protagonismo. De la misma manera, en los años iniciales del Setecientos, en plena guerra de Sucesión española, el último de los mencionados tribunales tendría un papel destacado en la forma de aconsejar al monarca sobre el mejor modo de gobernar sus posesiones, sobre todo, en el Atlántico.

\footnotetext{
21. COSTA, 2008.

22. MONTEIRO, 2015: 23-38.

23. BICALHO Y COSTA, 2017: 145
} 


\section{UNA COYUNTURA CRITTICA. LAS PRIMERAS DÉCADAS DEL SIGLO XVIII}

«O século XVIII começou crítico em Portugal. Na Europa, não houve como fugir do envolvimento na Guerra de Sucessão Espanhola, alinhando-se com a Inglaterra e contra as pretensões bourbônicas. Sobre as colônias, notadamente o Brasil, atiraram-se os corsários franceses, sempre de prontidão para correr uma costa já sua velha conhecida» ${ }^{24}$.

Así comienza el capítulo «A conjuntura crítica no mundo luso-brasileiro de inícios do século XVIIl» del volumen O Sol e a Sombra. Política e administração na América portuguesa do século XVIII, de Laura de Mello e Souza, marcado por dos tipos de peligros: el exterior y el interior ${ }^{25}$. Este tipo de argumentación se basó en una consulta a cargo de uno de los más doctos miembros del Conselho Ultramarino, António Rodrigues da Costa, escrita pocos días antes de su fallecimiento en $1732^{26}$. En ella, el experimentado consejero afirmaba que:

«A dois gêneros de perigos estão sujeitos todos os Estados, uns externos, outros internos: os externos são os da força e violência que poderão fazer as outras nações; os internos são os que poderão causar os naturais do país, e os mesmos vassalos. Ainda se pode considerar uma terceira espécie de perigo, qual é mais arriscada, e nasce dos dois primeiros; que é quando a força externa se une com a vontade e força interna dos mesmos vassalos e naturais ${ }^{27}$.

Se redefinía, en el Viejo Mundo, el poderío de las monarquías en el ámbito continental y, en sus dominios de Ultramar, la experiencia del corso que, en el caso específico de la América portuguesa, se había vivido con las dos consecutivas invasiones francesas, en I7Io y I7II, sobre Rio de Janeiro. La última, de funestas consecuencias para la hacienda real y para los bienes de sus vasallos, llevó a que el gobernador Francisco de Castro Morais, tras huir de la ciudad, negociase apresuradamente un rescate de 6Io.00o cruzados de oro, ioo cajas de azúcar y 200 cabezas de ganado, aunque sabía que desde la región de Minas Gerais descendía un refuerzo en hombres y armas capitaneado por el gobernador António de Albuquerque Coelho de Carvalho, que podría haber evitado dicho descalabro contra los franceses siempre y cuando las fuerzas de defensa de Rio hubiesen resistido algo más ${ }^{28}$.

Basta recordar lo que escribieron los oficiales municipales de Rio de Janeiro a respecto de Castro Morais. Decían no tener duda, «como era já público, ser ele o instrumento da nossa ruína», estando el «povo certo de que a entrega da praça foi

24. SOUZA, 2006: 78.

25. Ibidem. Véase también SOUZA, 2000: 459-473; y SOUSA y BICALHO, 2000.

26. FIGUEIREDO, 2006: 187-203.

27. «Consulta do Conselho Ultramarino a S.M., no ano de 1732, feita pelo conselheiro Antônio Rodrigues da Costa», Revista do Instituto Histórico e Geográfico Brasileiro, 7 (1866): 498-506.

28. BICALHO, 2003: 257-298. 
uma mera negociação». Los moradores de la ciudad hablaban abiertamente contra el gobernador, amenazando de motín, hasta el punto que pedían al soberano

«prostrados aos seus Reais pés, ponha os olhos neste miserável povo, em mandar consultar para o governo dele pessoas de toda a satisfação, como também ministro capaz de poder averiguar os desconcertos da entrega desta praça, para que com toda a severidade se castiguem os culpados nela, pois que de outra sorte terá Vossa Majestade sempre arriscada

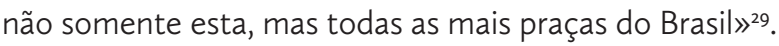

Las noticias provenientes de Brasil alarmaron a los ministros del Conselho Ultramarino. En una consulta de I7I2 advertían a Juan V:

«Senhor. A obrigação que tem este Conselho de procurar o bom governo, defesa e conservação das conquistas (...) faz preciso que todo ele (...) represente as perniciosas consequências que se seguem ao serviço de Vossa Majestade, ao bem público do Reino e de toda a Monarquia em se dilatar a nomeação de governador para o Rio de Janeiro, e de ministro que vá conhecer os delitos cometidos na entrega daquela Praça, para serem castigados condignamente os culpados neles; porque (...) tendo chegado a notícia a esta Corte há mais de três sem se haver nomeado governador nem ministro (...), se põe em perigo aquela Praça, que é uma das pedras mais preciosas que ornam a coroa de Vossa Majestade, de cuja conservação e bom

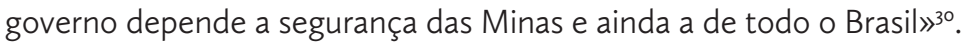

Lo que estaba en juego era el buen gobierno de las conquistas. Al monarca cabía nombrar personas que administrasen correctamente la justicia, que defendiesen los intereses reales y los de sus vasallos, y que no los desamparasen en momentos de peligro. En el caso contrario, los súbditos podrían rebelarse o amenazar de prestar vasallaje a otro señor, un rey extranjero.

En I7II, las alteraciones de Pernambuco, conocidas por la historiografía como la guerra dos Mascates ${ }^{3 \mathrm{I}}$, serían objeto de discusión por los consejeros de Ultramar. Su principal preocupación giraba en torno a las ventajas que podría alcanzar Francia de una coyuntura sediciosa en la América lusa. Recelaban que la noticia del levantamiento brasileño llegara a Europa y que Luis XIV enviase una escuadra para fomentarlo aún más,

«porque chegando à França a notícia desta alteração de Pernambuco, se pode recear que mande El Rei de França àquele porto uma esquadra a fomenta-la e introduzir-se por este modo naquela capitania, o que é muito próprio do orgulho e ambição da nação francesa e muito para temer da desesperação daqueles vassalos que abracem a proteção de El Rei de França» 32.

29. Araújo, 1820: 93-94.

30. AHU, Rio de Janeiro, Avulsos, caixa 9, documento 47. Consulta del Conselho Ultramarino, Lisboa, 20 de abril de 1712 (Se mantiene la antigua referencia archivística, posteriormente modificada).

31. Mello, 1995.

32. Consulta del Conselho Ultramarino, Lisboa, 26 de noviembre de 1711. Apud MELLO, 1995: 314. 
Los consejeros temían que la insatisfacción de los vasallos de Pernambuco los hiciese abrazar la protección francesa. Les parecía que si «este fogo da sedição, o qual já não é faísca pequena, mas incêndio grande» prendiese a otras regiones del Estado do Brasil, «comunicando-se de uma a outra, o que Deus não permita, (...) bem se deixa ver qual será o dano desta Monarquia»33.

Con la invasión y saqueo de Rio de Janeiro por los franceses, a la vez que Pernambuco estaba envuelto en una especie de guerra civil, en Salvador de Bahia, sede del gobierno general de Brasil, el pueblo se amotinó en I7II ante el intento de imposición de nuevos tributos como la décima de la Alfândega y los seis mil réis por esclavo enviado para las minas, junto al aumento del precio de la sal y la madera. Días después, al recibirse la noticia de la invasión francesa en Rio, los habitantes de Salvador volvieron a alterarse ante el intento de armarse un navío para expulsar a los galos y restaurar el dominio portugués en dicha urbe. El nuevo gobernador general, Pedro de Vasconcellos, no mostró pericia en su intento de subvenir a las diferentes causas de los motines. En el primero, los vasallos faltaron al respeto y obediencia debida al monarca, cuestionando la imposición tributaria. A pesar de merecer un castigo ejemplar, el gobernador los perdonó. En el segundo, aunque tumultuosamente, el pueblo se ofreció a defender Rio de Janeiro, demostrando empeño y celo en servir al rey. Ahora Vasconcellos fue demasiado enérgico y los castigó. Según los miembros del Conselho Ultramarino, el gobernador general no tuvo capacidad ni resolución para atajar ambas alteraciones, no demostrando fuerza ni determinación a la hora de ejecutar las órdenes reales y la imposición de los tributos ${ }^{34}$. Superados los tumultos y sosegados los ánimos, la recomendación del consejo era que Juan $V$ enviase un nuevo ministro a Bahia, «em quem concorram os requisitos ponderados de autoridade, prudência, e indústria, e que possa ser agradável àqueles povos, para que pelos meios da suavidade e brandura e com as razões da sua própria conveniência e conservação os persuada a aceitarem os novos impostos» ${ }^{35}$.

Nuevamente, lo que estaba en juego era la redefinición del poder real y la forma de su ejercicio en tan lejanos dominios. Se trataba, por tanto, de reforzar las prerrogativas del príncipe y de la justicia de su gobierno en tanto encarnado por sus representantes. Al rey cabía -y no al gobernador- castigar y personar a sus vasallos. En las críticas que el Conselho Ultramarino hacía sobre Pedro de Vasconcellos estaba implícita su censura al no tener jurisdicción para conceder el perdón a los colonos. Esta posibilidad sólo cabía al soberano con la condición sine qua non que aquéllos aceptasen las nuevas gabelas aplicadas a su defensa y la conservación del territorio.

El nuevo gobernador enviado a Bahia debería, por tanto, proceder «com grande dissimulação o que for necessário para por força fazer executar as ordens de Sua Majestade», preferiblemente a no ser que hubiese un intento de invasión enemiga sobre la ciudad de Salvador. Por los pasquines que habían circulado en la urbe brasileña, los revoltosos amenazaban con reconocer el vasallaje a otro señor si no se

33. Ibidem.

34. Consulta del Conselho Ultramarino, Lisboa, 27 de marzo de 1713, en Documentos Históricos, vol. 96. Rio de Janeiro, Biblioteca Nacional, 1952: 48.

35. Ibidem: 49. 
suspendían los nuevos tributos. En este caso, el gobernador debía resolver el asunto con blandura y persuasión, siendo la fuerza y el castigo reservados para una ocasión más sosegada. Así, en la visión de los consejeros, «o mais impenetrável muro que defende as povoações dos assaltos inimigos é a união dos moradores não só entre si, mas muito mais entre eles e quem os governa» ${ }^{36}$.

El miedo a una invasión extranjera, particularmente francesa, a Brasil no fue un sentimiento exclusivo de los que vivían en la colonia o la gobernaban. El temor suscitado por la amenaza ganó dimensiones extraordinarias en la corte lisboeta, sobre todo ante los ánimos exaltados de los colonos. Se vivía en Portugal con la expectativa creciente de una convulsión general de América. El pánico de los ministros de Juan $\mathrm{V}$ en esta amenazadora coyuntura bélica y de turbulencia de súbditos ultramarinos traducía el recelo de que la amenaza externa y el peligro interno confluyeran.

A fuerza de las crecientes amenazas extranjeras y de rebelión de vasallos en las distantes conquistas - por las violencias y vejaciones perpetradas por malos gobernantes, por la insoportable carga fiscal metropolitana, o por la dificultad de recurso al rey-, la política colonial portuguesa debía ser revisitada y sufrió, sin duda, una reformulación en la primera mitad del Setecientos. Así, como alertaba António Rodrigues da Costa en I7I2,

«as conquistas deste Reino se acham em manifesto perigo (...) pela grande inquietação dos ânimos dos seus habitadores, que contra a devida obediência e contra o sossego público multiplicam os motins e rebeliões, que são os princípios por onde caminham as Monarquias para a sua ruína»37.

En la mencionada consulta de I732, especie de testamento político del ministro luso, Rodrigues da Costa afirmaba que «a segunda causa da desafeição e ódio dos colonos ao governo do monarca nascia da dificuldade de recurso à Corte». Los naturales de América, individualmente o por medio de las câmaras de sus villas y ciudades, tenían el privilegio de corresponderse de forma directa con el rey, valiéndose de un dispositivo propio entre vasallos y soberanos desde tiempos inmemoriales: el llamado derecho de petición, que consistía en el envío de cartas -requerimientos, representaciones y quejas- al rey, solicitando mercedes a cambio de servicios prestados, quejándose de los malos gobernantes, exponiendo las violencias y vejaciones sufridas a lo largo y ancho de la monarquía portuguesa. Dicho sistema de solicitud no dejaba de ser una especie de canal de expresión de protesta autorizado por la Corona, que reconocía el poder terapéutico de manifestación de las aflicciones de los vasallos ante el soberano.

En Portugal, la comunicación directa con el monarca se difundía por la reunión de las cortes, asambleas convocadas esporádicamente por el rey para tratar de asuntos urgentes del reino, caso de la decisión de entrar en una guerra, el cobro

36. Consulta del Conselho Ultramarino, Lisboa, 27 de julio de 1712, en Documentos Históricos, vol. 96. Rio de Janeiro, Biblioteca Nacional, 1952: 49-52.

37. AHU, Rio de Janeiro, Avulsos, caixa 9, documento 62. Consulta del Conselho Ultramarino, Lisboa, 14 de octubre de 1712 . 
de un nuevo tributo o la aclamación de sus primogénitos, los futuros monarcas. En las cortes participaban procuradores de las ciudades, tanto del reino como -en ocasiones- de Ultramar ${ }^{38}$. Cuando se reunían, la ocasión era aprovechada para la presentación de todo tipo de solicitudes, agravios o quejas al rey. Dichas sesiones tenían un marcado significado simbólico, pues la presencia del monarca alimentaba la ficción de que todas las representaciones serían leídas y respondidas directamente por el soberano.

A lo largo del reinado de Juan V (I706-I750), estas asambleas nunca serían convocadas, ni siquiera durante la guerra de Sucesión española, cuando se aumentaron nuevos impuestos. Alegando urgencia y otras dificultades, el rey, asesorado por un número restringido de consejeros y ministros, deliberaba sobre su proyección sin consultar -como era tradicional- a los representantes de los pueblos o los municipios, lo que viene a corroborar el fortalecimiento del poder real, tan discutido por la historiografía. Por otro lado, la llegada a Lisboa de grandes cantidades de oro brasileño confirió al monarca facilidades políticas y financieras, garantizando mayor independencia de sus decisiones en relación a la tradicional consulta a los consejos y a los vasallos. Libre de la necesidad de recurrir a los tribunales o a los tres estados del reino (clero, nobleza, pueblo), Juan $\mathrm{V}$ deliberaría sin consultar a unas cortes que nunca más se reunirían durante el Setecientos. La remesa del oro de Brasil representó, para muchos estudiosos, el grandioso fasto barroco con que se envolvió la corte lisboeta del rey Juan, natural manifestación externa de su «absolutismo monárquico» ${ }^{39}$.

\section{LA DECLINACIÓN DE LA JURISDICCIÓN DEL CONSELHO ULTRAMARINO Y EL «ABSOLUTISMO» DE JOÃO V (1720-1750)}

Para la transición entre los siglos XVII y XVIII, Nuno Gonçalo Monteiro identifica importantes discontinuidades en el modo de gobernar. A su modo de ver,

«a regência e reinado de D. Pedro Il caracterizar-se-ão por um modelo de funcionamento da administração central que se prolongará ainda pelos primeiros anos do reinado de D. João V, mas que contrasta com o que foi adoptado desde, pelo menos, os anos 20 dos Setecentos, quando o rei passou a despachar com os seus sucessivos secretários de Estado ou outras personagens, em larga medida à margem dos conselhos, ou melhor, do Conselho de Estado» $4^{\circ}$.

A partir del gobierno efectivo de Pedro Il (I683-I706) la correspondencia entre la Corona y los cuerpos políticos de las conquistas -gobernadores, cámaras, proveedurías de la hacienda regia, etc- se gestionaba cada vez más -comparándose con los reinados precedentes de Juan IV y Alfonso VI- por la secretaría de Estado,

\footnotetext{
38. BICALHO, ROdRIGUES y CARDIM, 2017: 101-135.

39. Almeida, 1995: 183-207.

40. MONTEIRO, 2001: 967
} 
desde donde se encaminaban al Conselho Ultramarino. El titular de la oficina se correspondía intensamente con el presidente del tribunal y el secretario del mismo, interfiriendo en la decisión acerca de la prioridad de las consultas del consejo.

Con el inicio del Setecientos, la secretaría de Estado fue progresivamente absorbiendo las consultas de los requerimientos en torno a la remuneración de servicios, influyendo en el despacho de la secretaría das Mercês y en la circulación de papeles del Conselho Ultramarino. Así, poco después el titular de la primera se hizo con la segunda oficina, según el tenor del alvará regio de 24 de julio de I7I3 que reordenaría los circuitos del consilium al monarca y de la decisión real, todo ello en un momento en que se multiplicaba y complejizaba la labor administrativa del mencionado tribunal ultramarino respecto a un Estado do Brasil que asistía a una amplia estimulación político-económica de la colonia gracias a la producción de oro. La necesidad de organizar y disminuir el volumen de papeles y negocios en espera de la confirmación del soberano separaba los conductos por los que pasaban y eran decididas las mercedes menores -consultadas en los tribunales- y las gracias y asuntos de mayor relevancia, discutidos y confirmados por la firma del rey a través de la secretaría de Estado ${ }^{41}$.

La gran política -que gestionaba las alianzas exteriores y la guerra, la gestión ultramarina, el nombramiento de oficiales superiores, la remuneración de servicios, la decisión final de los pleitos judiciales y la administración tributaria-se transfirió de las consultas del Conselho de Estado al despacho directo de los secretarios que flanqueaban al monarca ${ }^{42}$. Luís Ferrand de Almeida alude al acentuado ostracismo de dicho tribunal supremo, sustituido por un círculo restrictivo de individuos y juntas de composición variable que pasaban a aconsejar al rey ${ }^{43}$. Entre los primeros destacaba el secretario de Estado Diogo de Mendonça Corte Real, hombre de gran peso en la decisión de Juan V. Tras doctorarse en Coimbra y con un destacado servicio diplomático en La Haya y Madrid, fue secretario das Mercês, siendo después nombrado secretario de Estado. Su correspondencia demuestra el extraordinario número de asuntos que controlaba. En el momento de su muerte, un informante español en Lisboa afirmó que era este plumista quien aseguraba la financiación de toda la monarquía lusa, recibiendo a los acreedores y negociando las deudas ${ }^{44}$.

A final de la década de I730, alguno de los principales asuntos brasileños, caso del desempeño e implementación de una reforma fiscal sobre el quinto de oro de Minas Gerais (según la capitación) o el negociado de los límites meridionales de América entre las Coronas de Portugal y Castilla, pasó a ser ampliamente influenciado por el secretario personal de Juan V, Alexandre de Gusmão, nombrado miembro del Conselho Ultramarino en I743. Asimismo, otros colaboradores directos del soberano asumirían igual o mayor importancia que cualquiera de los consejos o las secretarías.

\footnotetext{
41. Nogueira y HOMEM, 1996: 353-357.

42. MONTEIRO, 2006: 36-37.

43. AlmeidA, 1995: 192.

44. AGS, Estado, legajo 7182.
} 
Fue el caso del cardenal da Mota, quien -a decir de Luís da Cunha ${ }^{45}$ - fue entre 1736 y 1747 una especie de primer ministro ${ }^{46}$. De acuerdo con Nuno Monteiro,

«D. João $V$ foi sempre consultando quem quis, recorrendo a juntas e a diversos personagens para o efeito, nestes incluindo os velhos Cardeais Patriarca (D. Tomás de Almeida) e Inquisidor-Mor (D. Nuno da Cunha). No entanto, embora sem título formal de 'primeiroministro', era o Cardeal D. João da Mota e Silva, irmão de Pedro da Mota [futuro secretário de Estado], que o rei ouvia sobre todas as matérias relevantes, até a morte deste, ocorrida em $1747 \gg^{47}$.

Un episodio que comprueba el protagonismo del purpurado en el consilium al rey -o de su confianza a la hora de consultarlo para negocios de alta relevancia- ocurriría tras la muerte del mencionado secretario Diogo de Mendonça Corte Real. En dicho momento, Juan $\mathrm{V}$ requirió su opinión acerca de un papel escrito por el cardenal da Cunha sobre la necesidad del desdoblamiento de la antigua secretaría de Estado en cuatro oficinas diferenciadas. En su respuesta, el purpurado afirmaba que «o que a mim me tem ocorrido, e em que assento por melhor é que as Secretarias, e secretários sejam todos, e todas, com o nome de Estado, e que não passem das três (...)». Tras reflexionar sobre «a qualidade dos diferentes negócios», proponía la creación de una secretaría dos Negócios Estrangeiros ante la consideración que «estes por si só não ocupam entre nós uma Secretaria, e a eles pertencem os tratados de paz e guerra, e comércio exterior», siendo preciso unificar el expediente de la guerra y la milicia ${ }^{48}$.

En cuanto a la segunda secretaría, debía de ser de Marinha e Ultramar, cuyo secretario tendría mucho

«em que trabalhar nas correspondências dos vice-reis, governadores e ministros de todas as Conquistas, nas consultas do Conselho Ultramarino e nas do Conselho da Fazenda que respeitam à Índia, Ilhas e Mazagão, e aos Armazéns, e da Mesa da Consciência quanto às igrejas do Ultramar, e do Conselho de Guerra dos postos da Marinha, ofícios da mesma Marinha, e despachos de mercês de toda a dita repartição»49.

La tercera habría de llamarse Secretaria da Repartição do Reino, «ou Reinos, metendo o Algarve», que abarcaría todo asunto de negocios y, sobre todo, del cuidado en el despacho de los demás tribunales, excepto los de Guerra y el Ultramarino ${ }^{50}$.

Las tres Secretarias de Estado concentrarían, así, de forma más eficaz las diveras materias gubernativas de la monarquía portuguesa, por lo que terminaron tomando cuerpo en 1736.

45. Sobre D. Luís da Cunha, véase CunHA, 2001, así como el artículo del presente monográfico a cargo de Júnia Ferreira Furtado.

46. Almeida, 1995: 192-193; MonTeiro, 2010: 351.

47. MONTEIRO, 2015: 23-38.

48. BNP, Reservados, códice 8058, ff. 240-243.

49. Ibidem.

50. Ibidem. 
De acuerdo con Miguel Cruz, a mediados de la década de I730, el Conselho Ultramarino experimentó grandes mudanzas y una disminución de poder aparentemente irreversible. Las razones para estos cambios pueden encontrarse en el hecho de que, desde I7I4, el tribunal carecía de un presidente titular. En segundo lugar, había perdido «a voz mais escutada por D. João V em matérias ultramarinas», la del consejero António Rodrigues da Costa, fallecido en I732. Finalmente, el tribunal había sido reestructurado entre 1729 y I730, sufriendo una profunda reducción de competencias en el cuadro de la administración de recursos financieros destinados a la defensa del imperio. Más allá de esto, a mediados de la década de I720, la estructura de la financiación del consejo sufrió una amplia reformulación, con la privación de los porcentajes provenientes de las rentas totales de las grandes capitanías brasileñas de Bahía, Pernambuco y Río de Janeiro. El golpe de gracia provendría, en i76I, con la creación del Erário Regio, un último acto con que se despojaron las competencias remanentes del Conselho Ultramarino respecto a la gestión de recursos destinados a la protección de las conquistas, pues perdió todo derecho para interferir en la hacienda real de tales territorios en pro del nuevo organismo ${ }^{51}$.

\section{¿REVIRTIENDO, O NO, EL FRACASO?}

Las dinámicas institucionales y jurisdiccionales que afectaron a la política monárquica e imperial de Portugal en el Antiguo Régimen se basaban en distintas formas de resolver y despachar los negocios. Por un lado, en el régimen consiliario o gobierno de los consejos, preponderante hasta finales del siglo XVII; por el otro, a partir del reinado de Juan $V$, y pese a que no se excluyó por entero a la consulta de los tribunales, se vivió una mudanza de los centros de decisión política, destacando el rol de las juntas y las secretarías de Estado que apuntaban a un gobierno de carácter ministerial.

Un documento extraordinario de hacia 1746 sobre el declive de las consultas de los tribunales, y de la pérdida de prestigio y jurisdicción de los consejos como el de Ultramar -que puede entenderse como el progresivo fracaso del sistema polisinodialse articula como la carta que un autor anónimo remitió a un destinatario apuntado como V. P. (Vossa Paternidade) -posiblemente, el cardenal da Mota-:

«Ordena V. P. que lhe diga meu parecer sobre este modo de resolver e despachar os negócios, que agora se usa, mandando-se ver em juntas, que se fazem nas Secretarias com diversos ministros que os Secretários chamam da parte de Sua Majestade. Essa dúvida que V. P. me propõe assenta sobre um estilo que tem lançado muito altas raízes, porque desde que El Rey nosso Senhor governa, que há quarenta anos (...), se usa dele, e assim entendo que seu estilo não é bom. (...) Ihe afirmo, que o tive sempre, e tenho por muito danoso ao serviço de Deus, ao d'El Rei e República, assim em comum pelo que toca aos negócios dela, como em particular pelo que toca à justiça das partes $»^{52}$.

51. CRUZ, 2015: 93-95.

52. ANTT, Casa Real, caixa 3740. Todas las referencias citadas provienen del mismo documento. Agradezco a 
El anónimo autor consideraba hacer esta afirmación por experiencia personal, pues desde el inicio del gobierno de dicho monarca formó parte de innumerables juntas e, incluso, en un año llegó a integrar todas las que se organizaron. Aludía al antiguo sistema:

«Este Reino desde seu princípio se governou sem juntas, e não tratando agora do que se usava nas suas primeiras idades, nas quais quase todos os negócios se despachavam pelos Reis, ouvindo os do seu Conselho, e falando do tempo das idades mais adultas, se ordenavam os tribunais, repartindo a cada um deles os negócios a que haviam de deferir. De modo que não há negócio algum, ou seja da República, ou das partes, que não pertençam a algum dos tribunais, e estes têm seus regimentos, e suas leis, que os Príncipes Ihe foram dando para a expedição dos altos negócios, ou já seja para os poderem deferir, ou para os deverem consultar».

Argumentaba también que las juntas se habían convocado tanto para revalidar negocios ya consultados en los consejos, como para decidir cuestiones que no pasaron anteriormente a otros tribunales supremos. Los que se mostraban favorables a este procedimiento defendían la importancia del secreto en la conducción y resolución de los negocios respectivos. Afirmaba, a su vez, que muchas veces, en nombre del secreto se cometían injusticias bien por no ser oídas las partes solicitantes, bien por arbitrar de acuerdo al parecer de un «ministro informante» que podía ser -como de facto solía ocurrir- un «inimigo capital» del peticionario.

En cuanto a los negocios previamente tratados por los consejos competentes, y que posteriormente se mandaban a la junta para dar su parecer,

«é maior o escândalo, porque se aqueles ministros aos quais Sua Majestade tem escolhido para o aconselharem, e estão com autoridade Real propostos a seus povos, (...) havendo visto o negócio no tribunal, e os papéis originais dele, ouvido as partes, e tomado as informações, não acertarem; que mais razão tem de acerto os que não vêem mais que a consulta, para votarem, como votam nela, tanto que se acaba de ler?».

El autor del papel aún consideraba que los ministros nombrados para los tribunales eran «menos dependentes dos poderes e dos afetos». Ya en las juntas, muchas veces en vez de ser nombrados por el rey, los ministros eran escogidos por el secretario, y si «não forem de parecer com que os do despacho estão, vem outros, e outros até se dar com alguns que concordem com o que se intenta, e (...) tanto que se dá com estes logo então por seu parecer se resolve, e todos os outros votos ficam cassados».

Sobre el modo de votar en las juntas,

«frequentissimamente sucede que os Secretários têm outras ocupações a que acudir, e estão para ir a despacho com Sua Majestade, espertam [sic] com os ministros que digam seu parecer muito depressa, e assim dizem arrebatada e precipitadamente, sem toda aquela ponderação

André Costa la indicación de este documento. 
e consideração que pede a gravidade dos negócios, dos quais a maior ruína costuma ser a brevidade com que neles votam, pois esta é capital inimiga dos acertos».

Esta no sería, ciertamente, la única voz que recordaba con pesar la tradición inmemorial del gobierno de la monarquía portuguesa y, así, contraria al nuevo modo de resolverse y despachar los negocios por medio de juntas y secretarías. No sería también la última. Durante la segunda mitad del siglo XVIII, con el gobierno de José I (I750-I777) y bajo la influencia del secretário do Reino, Sebastião José de Carvalho e Melo, futuro marqués de Pombal, la forma de gobierno ministerial se consolidó, llevando a una reducción de la jurisdicción de los tribunales, como el Conselho Ultramarino.

Por este motivo, los miembros de este consejo no dejaron de reclamar sus competencias frente a los sucesivos monarcas lusos, de acuerdo con lo que disponía el regimiento del tribunal. El I4 de marzo de I777, tras el fallecimiento de José I y el inicio del reinado de María I, una consulta del Ultramarino recordaba a la soberana la cláusula de su institución sobre la obligatoriedad de que toda la correspondencia de los ministros de las conquistas debía remitirse al consejo, pese a la práctica en contrario. Así, el mencionado parecer se iniciaba de la siguiente forma:

\begin{abstract}
«Senhora. Pelo parágrafo sexto do regimento deste Conselho se declarou pertencerem ao seu conhecimento todas as matérias e negócios de qualquer qualidade que fossem respectivos aos Estados da Inndia, Brasil, Guiné, Ilhas de São Tomé, Cabo Verde e a todas as mais partes ultramarinas, excetuadas tão somente as Ilhas dos Açores, Madeira e lugares de África, declarando-se outrossim no parágrafo sétimo que a este mesmo Conselho viriam remetidas todas as cartas e despachos de todos os ministros, prelados e quaisquer outras pessoas dos sobreditos Estados, como se vê da cópia do mesmo regimento, que com esta sobre à Real presença de Vossa Majestade».
\end{abstract}

Los consejeros afirmaban haberse alterado, casi totalmente, esta formalidad, lo que provocaba que el consejo no tuviese noticia de las diversas órdenes expedidas a los gobernadores y demás ministros de Ultramar. A los oficiales reales se daban instrucciones particulares ignoradas por el tribunal, pese a la jurisdicción al respecto. Y, finalmente, los consejeros desconocían los informes y negociados de los ministros del Além-Mar, una independencia que «lhes dá ocasião para que só respondam e observem aquelas [órdenes] que se conformam com os seus arbítrios». Decían, incluso, que

«Esta falta de noção daquelas ordens e particulares instruções se persuade o Conselho ser muito prejudicial não só ao Real serviço de Vossa Majestade e à arrecadação da sua Real Fazenda, mas ainda ao bem comum e particular dos seus fiéis vassalos, porque não podendo dela resultar senão desordem e confusão, são estas totalmente impeditivas de se chegar ao acerto com que este Conselho desejou sempre conduzir-se no Real serviço de Vossa Majestade, e de seus augustíssimos predecessores» ${ }^{53}$.

53. AHU, Conselho Ultramarino, caixa 5, documento 463. 
Miguel Cruz, en su ensayo sobre el Conselho Ultramarino y la defensa de Brasil, presenta una versión interesante sobre el decrecimiento de la importancia del tribunal y su «luta inglória para recuperar jurisdição». Centrado, sobre todo, en la cuestión específica de las provisiones de patentes militares en la América portuguesa, a su parecer dicho descaecimiento no benefició prioritariamente al protagonismo de los secretarios lisboetas, sino potenció con una mayor centralidad -y autoridada gobernadores como los de Río de Janeiro y Bahía ${ }^{54}$. Es una lectura innovadora que ofrece ponderaciones importantes para el análisis de la segunda mitad del Setecientos, cuando se delinerará una nueva coyuntura sediciosa -mucho más diversa y crítica que la primera- en el horizonte, aunque escapa del análisis de este estudio. Bien a favor de las secretarías de Estado, bien de los gobernadores ultramarinos, el declive del Conselho Ultramarino en cuestiones relativas a las conquistas era ya un hecho irreversible.

54. CRUZ, 2015: 382-386. 


\section{BIBLIOGRAFIA}

AlmeidA, Luís Ferrand de, «O absolutismo de D. João V», en Luís Ferrand de Almeida, Páginas Dispersas. Estudos de História Moderna de Portugal, Coimbra, Instituto de História Económica e Social / Faculdade de Letras da Universidade de Coimbra, I995: I83-207.

Araújo, José de S. A. Pizarro de, «Terceira Memória perpetuada na conta que deu o Senado a El Rei, em data de 28 de Novembro do mesmo ano de I7II», en José de S. A. Pizarro de Araújo, Memórias Históricas do Rio de Janeiro, Tomo I, Rio de Janeiro, Impressão Régia, I820.

BArros, Edval de Souza, Negócios de tanta importância. O Conselho Ultramarino e a disputa pela condução da guerra no Atlântico e no Índico (I643-I66I), Lisboa, Centro de História de Além-Mar, 2008.

Bicalho, Maria Fernanda, A Cidade e o Império. O Rio de Janeiro no século XVIII, Rio de Janeiro, Civilização Brasileira, 2003.

Bicalho, Maria Fernanda, Rodrigues, José Damião y CARdim, Pedro, «Cortes, juntas e procuradores», en João Fragoso y Nuno Gonçalo Monteiro (eds.), Um Reino e suas Repúblicas no Atlântico, Rio de Janeiro, Civilização Brasileira, 20I7: IOI-I35.

BiCALHO, Maria Fernanda y CosTA, André da Silva, «O Conselho Ultramarino e a emergência do Secretário de Estado na comunicação política entre reino e conquistas», en João Fragoso y Nuno Gonçalo Monteiro (eds.), Um Reino e suas Repúblicas no Atlântico, Rio de Janeiro, Civilização Brasileira, 20I7: 137-I58.

Borges, Graça Almeida, Um império ibérico integrado? A União Ibérica, o Golfo Pérsico e o império ultramarino português (I600-1625), tesis doctoral inédita, Florencia, European University Institute, 2014.

Caetano, Marcello, O Conselho Ultramarino. Esboço de sua história, Lisboa, Agência Geral do Ultramar, 1967.

Cardim, Pedro, Cortes e Cultura Política no Portugal do Antigo Regime, Lisboa, Edições Cosmos, I998.

CARdim, Pedro, «A Casa Real e os órgãos centrais do governo de Portugal da segunda metade de Seiscentos», Tempo, I3/7 (2002): 13-57.

Costa, André da Silva, Os secretários de Estado do Rei: Luta de corte e poder político, séculos XVI-XVII, tesis de máster inédita, Lisboa, Universidade Nova de Lisboa, 2008.

Costa, Leonor Freire y Cunha, Mafalda Soares da, D. João IV, Lisboa, Círculo dos Leitores, 2006.

CRuz, Miguel Dantas da, Um Império de conflitos. O Conselho Ultramarino e a defesa do Brasil, Lisboa, Imprensa de Ciências Sociais, 2015.

Cunha, Luís da, Instruções políticas (edición de Abílio Diniz Silva), Lisboa, Comissão Nacional para as Comemorações dos Descobrimentos Portugueses, 200I.

Elliotr, John H., El Conde-Duque de Olivares, Barcelona, Crítica, 2012.

Feros, Antonio, El Duque de Lerma. Realeza y privanza en la España de Felipe III, Madrid, Marcial Pons, 2002.

Figueiredo, Luciano Raposo de Almeida, «Antônio Rodrigues da Costa e os muitos perigos dos vassalos aborrecidos (notas a respeito de um parecer do Conselho Ultramarino, I732)», en Ronaldo Vainfas, Georgina da Silva Santos y Guilherme Pereira das Neves (eds.), Retratos do Império. Trajetórias individuais no mundo português nos séculos XVI a XIX, Niterói, Ed. UFF, 2006: 187-203. 
Loureiro, Marcello José Gomes, lustitiam Dare. A Gestão da Monarquia Pluricontinental: Conselhos Superiores, pactos, articulações e o governo da monarquia pluricontinental portuguesa (I640-I668), tesis doctoral inédita, París-Rio de Janeiro, EHESS-PPGHISUFRJ, 2014.

Luz, Francisco Paulo Mendes da, O Conselho de Índia. Contributo ao Estudo da História da Administração e do Comércio do Ultramar Português nos princípios do século XVII, Lisboa, Agência Geral do Ultramar, 1952.

Mello, Evaldo Cabral de, A Fronda dos Mazombos. Nobres contra Mascates. Pernambuco, I666-I715, São Paulo, Companhia das Letras, I995.

Monteiro, Nuno Gonçalo, «Identificação da política setecentista. Notas sobre Portugal no início do periodo joanino», Análise Social, XXXV/I57 (200I): 96I-987.

Monteiro, Nuno Gonçalo, D. José, Lisboa, Círculo dos Leitores, 2006.

Monteiro, Nuno Gonçalo, «A monarquia barroca», en Rui Ramos, Bernardo Vasconcelos e Sousa y Nuno Gonçalo Monteiro (eds.), História de Portugal, Lisboa, A Esfera dos Livros, $2 \mathrm{OIO}^{2}$.

Monteiro, Nuno Gonçalo, «A Secretaria de Estado dos Negócios do Reino e a administração de Antigo Regime (I736-I834)», en Pedro Tavares de Almeida y Paulo Silveira e Sousa (eds.), Do Reino à Administração Interna: História de um Ministério (I736-20I2), Lisboa, Imprensa Nacional, 2015: 23-38.

Nogueira, J.A. Duarte y Homem, A. P. Barbas, «Secretário de Estado», en Dicionário Jurídico da Administração Pública, vol. VIl, Lisboa, I996: 353-357.

Schaub, Jean-Frédéric, Le Portugal au Temps du Comte-Duc Olivares (I62I-I640), Madrid, Casa de Velázquez, 200I.

SouzA, Laura de Mello, «Motines, revueltas y revoluciones en la América Portuguesa de los siglos XVII y XVIII », en Enrique Tandeter y Jorge K. Lehuedé (dirs.), Historia General de América Latina, vol. IV, Buenos Aires, Ediciones UNESCO / Editorial Trotta, 2000: 459-473.

Souza, Laura de Mello e y Bicalho, Maria Fernanda B. 1680-I720, O império deste mundo, São Paulo, Companhia das Letras, 2000.

SouzA, Laura de Mello e, «A conjuntura crítica no mundo luso-brasileiro de onícios do século XVIII», en Laura de Mello e Souza, O Sol e a Sombra. Política e Administração na América Portuguesa do século XVIII, São Paulo, Companhia das Letras, 2006.

Xavier, Ângela Barreto y CARDim, Pedro, D. Afonso VI, Lisboa, Círculo dos Leitores, 2006. 


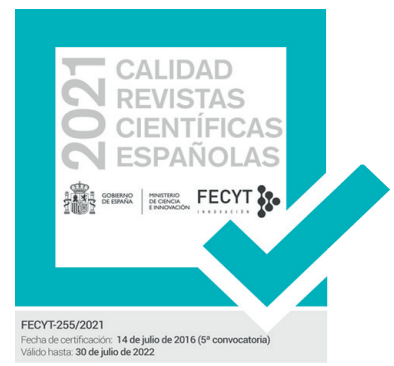

SERIE IV HISTORIA MODERNA

REVISTA DE LA FACULTAD DE GEOGRAFÍA E HISTORIA

AÑO 2021

ISSN: 1131-768X

E-ISSN 2340-1400

\section{4 \\ 西 ESPACIO, TIEMPO Y FORMA}

Monográfico - Special Issue: La política ultramarina de las monarquías ibéricas (circa 1700-1750): una historia de fracasos y éxitos relativos The Overseas Policy of the Iberian Monarchies (Circa 1700-1750): A History of Failures and Relative Successes

15 Roberto Quirós Rosado y MARIA FERnANDA BICALHO La política ultramarina de las monarquías ibéricas (circa 1700-1750): una historia de fracasos y éxitos relativos / The Overseas Policy of the Iberian Monarchies (Circa 1700-1750): A History of Failures and Relative Successes

\section{Guillaume Hanotin}

Defender negocios en tiempo de convulsión política: las elites mercantiles francesas durante la guerra de Sucesión española / Protecting Business in Time of Crisis: French Trademen during the War of Spanish Succession

\subsection{Maria Fernanda Bicalmo}

Ultramarino y el auge de los secretarios de Estado en Portugal durante la primera mitad del siglo XVIII / Sobre este modo de resolver e despachar os negócios. The decline of the Overseas Council and the Rise of the Secretaries of State in Portugal during the First Half of the $18^{\text {th }}$ Century

\section{9}

\section{VALENTINA FAVARò}

El fracaso de los proyectos de reforma en el virreinato peruano de principios

del siglo XVIII. Las propuestas de Carmine Nicola Caracciolo, príncipe de Santobuono the Eighteenth Century. The Proposals of Carmine Nicola Caracciolo, Prince of Santobuono

\section{7}

\section{ROBERTO QUIRÓS ROSADO}

Ecos de un mercantilismo truncado. El conde de Pinos Puente y la diplomacia comercial de Carlos VI en la corte de Lisboa (1723-1724) / Echoes of a Failed Mercantilism. The Count of Pinos Puente and the Commercial Diplomacy of Charles VI at the Court Of Lisbon (1723-1724)

\section{Junia Ferreira Furtado}

Portuguese America under Foreign Threat and the Creation of the Concept of uti possidetis in the First Half of the $18^{\text {th }}$ Century / La américa portuguesa bajo la amenaza exterior y la creación del concepto de uti possidetis en la primera mitad del siglo XVIII

\section{Miscelánea $\cdot$ Miscellany}

\section{José Antonio Mateos Royo}

con Cataluña / Trade Policy and Monetary Circulation in Aragon: Conflicts and Agreements with Catalonia (1535-1565)

\section{Fernando Altoé}

panegíricos atribuidos a la impresion. Un estudio de la trayectoria de dos the Trajectory of Two Panegyrics Attributed to João de Barros

\section{Francisco Velasco Hernández}

reino de Murcia (siglos XVI y XVII) / The Influence of the Berber Corsican on the Late Repopulation on the Coastal Area on the Kingdom of Murcia (XVI and XVII Centuries)

\section{José Antonio Martínez Martínez}

Criados, jornaleros y esclavos al servicio de la familia: la servidumbre de Serfdom of the Muñoz de Otálora in the $17^{\text {th }}$ Century

\section{Víctor Daniel Regalado González-Serna}

Benito de Medina a raíz de su ingreso en el cabildo catedral de Sevilla en 1669 / «Not a Single Good Portuguese». Accusations against Priest Alonso Benito de Medina when Entering the Cathedral Chapter of Seville in 1669

\section{José Herrera Reviriego}

organigrama comercial y militar de la Gober a tólo mitad del siglo XVII / "Only Time will Tell us»: The Role of Taiwan within the Commercial and Military Organization of the Philippine's Governoration during the First Half of the Seventeenth Century

\section{Manuel-Reyes García Hurtado}

de Rande, 1719-1733 / Vicissitudes of the Rescue Companies of the Sunken Ships in the Battle of Rande, 1719-1733

\subsection{Marcos de Miguel Muñoz}

Caballeros in 1769 


\section{4 ESPACIO, TIEMPO Y FORMA}

\section{Javier Tinoco Domínguez}

Tensiones sociopolíticas en el marco del catastro de Ensenada en Jerez de la Frontera: estudio de un conflicto institucional / Socio-Political Tensions within the Framework of Cadastre of Ensenada In Jerez de la Frontera: A Studying of an Institucional Conflict

\section{Pablo Fernández Albaladejo}

Fábulas de origen y gramática de nación en la España del siglo XVIII. A propósito de algunos trabajos de Francisco Martínez Marina / Origin's Fables and Grammar of Nation in the XVIII Century Spain. About some Works by Francisco Martínez Marina

\subsection{José María IÑURRITEgui Rodríguez}

Constitución increada: Francisco Martínez Marina y la crítica bíblica / Uncreated Constitution. Francisco Martínez Marina and Biblical Criticism

\subsection{David A. Abián Cubillo}

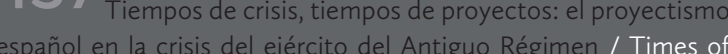
crisis, Times of Projects: The Spanish proyectismo during the Army's Crisis in the Ancient Regime

Taller de historiografía · Historiography Workshop

\section{Ensayos · Essays}

\subsection{ChrISTOPH ROSENMÜLLER}

«Tan peligrosas y feas conspiraciones»: la relación escrita por el embajador austriaco Christoph Migazzi en 1754 sobre la caída del marqués de la Ensenada / «Dangerous and Ugly Conspiracies». The Report of the Austrian Ambassador Christoph Migazzi on the Fall of the Marquis of la Ensenada in 1754

\subsection{Serge Gruzinskı}

Quelle histoire enseigner en 2021 ? / ¿Qué historia enseñar en 2021?

\subsection{Carlos Amate Pizarro}

Las relaciones hispano-chinas en el siglo XVI: síntesis e interpretación a la luz de la reciente historiografía / The Hispanic-chinese Relationship in the XVI Century: Synthesis and Interpretation in the Light of Recent Historiography

\section{Reseñas • Book Review}

521 Bolufer Peruga, Mónica, Arte y artificio de la vida en común. Los modelos de comportamiento y sus tensiones en el Siglo de las Luces, (Julio ArRoyo Vozmediano) 


\section{4 ESPACIO, TIEMPO Y FORMA}

525 Melón, Amando, Alejandro de Humboldt. Vida y obra (Carlos Martínez Shaw)

52 Commentary to Tatiana Seijas' review of The Atlantic World and the Manila Galleons: Circulation, Market, and Consumption of Asian Goods in the Spanish Empire (JosÉ LuIs GASCH TOMAS)

533 Braguier, Laurey, Servantes de dieu. Les beatas de la Couronne de Castille (1450-1600) (Manuela Águeda GARCÍA-GARRIDO)

539 Romeo, María CRuz; SAlomón, María Pilar; TABANERA, Nuria (eds.): Católicos, Reaccionarios y Nacionalistas. Política e identidad nacional en Europa y América Latina Contemporáneas (JAVIER M. Dos SANTOS)

54 Heredia López, Alfonso Jesús, El control de la corrupción en la Monarquía Hispánica. La Casa de la Contratación (1642-1660) (José Manuel Díaz Blanco)

17 Andújar Castillo, Francisco, El Atila de Madrid. La forja de un banquero en la crisis de la monarquía (1685-1715) (Aitor Díaz PAREdes)

551 Serrano Aviles, Javier y Mojarro, Jorge (eds.) Prada GonzALEZ, María (coord. de ilustraciones), En el archipiélago de la Especiería. España y Molucas en los siglos XVI y XVII (İ̃̃ıGo VALPUESTA VILLA)

555 Díaz Ceballos, Jorge, Poder compartido. Repúblicas urbanas, Monarquía y conversación en Castilla del Oro, 1508-1573 (JUAN SEbAstián Gómez GonZÁleZ)

51 Edelmayer, Friedrich, Massimiliano II, Filippo II I'Italia imperiale. II marchesato di Finale, i diritti imperiali e il «camino spagnolo» (RAFAEL VALLADARES)

56 Escribano-PÁEZ, José M., Juan Rena and the Frontiers of Spanish Empire, 1500-1540 (DAvid Martín Marcos)

56 ARnOLD, David, La Era de los Descubrimientos (1400-1600), Madrid, Alianza Editorial, 2021, 184 Pp., ISBN: 978-841362-172-2 (CARlos Amate Pizarro) 